\title{
THE ANEMIA OF THERMAL INJURY. II. STUDIES OF LIVER FUNCTION 1, 2
}

\author{
By G. WATSON JAMES, III,3 OLIVER J. PURNELL,“ AND EVERETT I. EVANS, 5 \\ WITH THE TECHNICAL ASSISTANCE OF VIVIAN WILKERSON AND \\ ANNE ANDERSON \\ (From the Laboratory for Clinical Investigation, Department of Medicine, and the Surgical \\ Research Laboratory, Department of Surgery, Medical College of Virginia, Richmond)
}

(Submitted for publication September 7, 1950; accepted, November 6, 1950)

In a previous communication it was demonstrated that an increased excretion of urine urobilinogen was an early and constant finding in thermal injury even in burns of a relatively small amount of third degree (1). Since this particular finding was interpreted by us as a manifestation of hepatic injury, we undertook the further study of certain liver function tests in burned patients, none of whom received sulfonamides, tannic acid or other escharing therapy.

Bardeen published a review of the pathology of severe burns in 1899 and noted at that time changes in the liver and the kidney (2). Wolff, Elkinton and Rhoads demonstrated in three burn patients B.S.P. retention, slight icterus, and a decreased glucose tolerance as well as a decreased hippuric acid excretion test for liver function (3), and Boyce records similar observations and remarks upon the manifestation of jaundice in 65 per cent of the burn patients reported by him (4).

The histopathology of liver changes from 21 to 57 hours after injury has been described as fatty metamorphosis of the epithelial cells in the central zone of the hepatic lobules, and nuclear damage, especially karyolysis. After 57 hours there is slight enlargement, the liver is lighter yellow, greasy, friable, and has venous congestion of the "nutmeg" type. In addition there is evidence of

1 Presented in part before the Clinical Congress, American College of Surgeons, October 16-23, 1949, Chicago, Illinois.

2 Supported by grants to the Surgical Research Laboratory, Department of Surgery, from the Medical Research and Development Board, Department of the Army (Project: S.F. No. W-49-005-MD-411).

${ }^{3}$ Markle Scholar in Medical Sciences, formerly Post doctorate Research Fellow of the National Institutes of Health.

4 Surgical Research Fellow.

- Director of the Surgical Research Laboratory, Medical College of Virginia. degeneration and necrosis (5). It was believed that the central rather than the peripheral zone was first affected. Gillman and Gillman examined the livers of 38 patients dying within one hour and up to 36 days after burns and showed fatty changes and atrophy of the cells in the central zone. Eight days seemed to be necessary for the development of a very fatty liver, and it would appear that tannic acid intensified the tendency toward necrosis, which they believe present in some patients with burns. However, the majority of the microscopic liver changes were insufficient to account for a fatal termination. They concluded that if the liver contributed to death it did so through altered biochemical effects. It was the opinion of some that tannic acid therapy was responsible for precipitating liver damage (6) and the liver damage from tannic acid was central in character (7). Duffin reports an autopsied case with severe liver failure (8). Hepatic necrosis by his standard occurred in only six patients. Baker made an analysis of 87 autopsied burns on whom liver sections were available. In 56 death occurred before the sixth day. In only three of these was necrosis sufficient to involve nearly one-half the liver lobule, and all of these succumbed on the eighth day after burning. None received tannic acid. He concludes that minimal hepatic necrosis may. apparently be caused by burns. Histologically demonstrable fat was frequently seen in those patients dying in the first 24 hours, and in those dying after four weeks. He concludes that necrosis of the liver is not a lesion characteristic of burns (9).

Hartmann and Romence studied liver damage in dogs and found gross enlargement of both the liver and spleen (10). In acute experiments of four to ten days, histopathology demonstrated hepatic lesions ranging from marked congestion of the sinusoids and compression of the liver cords 
to varying amounts of granular, vascular, and fatty degeneration. Central necrosis occurred in eight to ten days, and liver function was depressed. They did not find the picture of acute liver insufficiency. Belt (11) believes the liver necrosis following burns simulates the lesions of yellow fever and described Councilman bodies and nuclear inclusion bodies. His patients had tannic acid treatment.

\section{METHODS AND MATERIALS}

Fifteen burn patients admitted to the Burn Service of the Department of Surgery of the Medical College of Virginia were selected for study. The majority of the burns were usually of the free fire type from kerosene explosions on wood stoves or blazing clothing. Blood for liver function tests was taken on admission and repeated at intervals during the course of the treatment. In some instances only one set of determinations could be obtained because of early demise or difficulty in obtaining blood. Treatment in all cases was essentially the same and employing pressure bandages without debridement. Parenteral antibiotics, whole blood and replacement fluid therapy were used as needed clinically. No tannic acid, escharing agent, or sulfonamides were employed. In some instances the patients during the course of study were on a special liquid diet providing $100 \mathrm{Gm}$. of protein, with sufficient fat and carbohydrate to give an average of 45 Calories per kilogram, and vitamin supplements as recommended by the National Research Council.

The following liver function tests were performed: Bromsulfalein retention using $5 \mathrm{mg}$. per kilogram and taking a 45 minute sample (12); cephalin-cholesterol flocculation at the modified $\mathrm{pH}$ of 7.4 (13) ; thymol tur- bidity (14) ; prothrombin time employing the one stage method of Quick (15); total protein and albumin-globulin ratio (16) ; the serum bilirubin employing the DucciWatson modification of the Malloy and Evelyn technique $(17)$; and the quantitative urine urobilinogen (18).

As in a previous study the patients were separated into three clinical groups on the basis of the amount of surface area involved by third degree burn. There were five patients in Group I who had burns of from 0 to 11 per cent third degree; three in Group II, 12-20 per cent; and seven whose burns were greater than 21 per cent in Group III.

Autopsy material was obtained on five of the six patients in Group III, all of whom expired.

\section{RESULTS AND DISCUSSION}

Table I gives the composite results of the liver function tests on all 15 patients as performed within the first ten days (usually within the first five days) after the burn. The most constant finding is an increased amount of urobilinogen in the urine, which in one instance reached as high as $75 \mathrm{mg}$. per day.

In the five patients who had less than 10 per cent third degree burns we see there was bromsulfalein retention of greater than 20 per cent in two of the three patients in whom this test was performed. In four of the five patients there was an elevation of the thymol turbidity test to greater than four units which is considered the upper limit of normal in our laboratory. Two of the four patients in whom the cephalin-cholesterol floccula-

TABLE I

Composite table of liver function studies

\begin{tabular}{|c|c|c|c|c|c|c|c|c|c|c|c|c|c|c|}
\hline & \multirow{2}{*}{ Patient } & \multirow{2}{*}{ Age } & \multirow{2}{*}{$\operatorname{Sex}$} & \multirow{2}{*}{ retention } & \multirow{2}{*}{$\begin{array}{l}\text { Cephalin } \\
\text { floccula- } \\
\text { tion }\end{array}$} & \multirow{2}{*}{$\begin{array}{l}\text { Thymol } \\
\text { turbidity }\end{array}$} & \multirow{2}{*}{$\begin{array}{l}\text { Pro- } \\
\text { thrombin } \\
\text { concen- } \\
\text { tration }\end{array}$} & \multirow{2}{*}{$\begin{array}{c}\text { Urine } \\
\text { urobili- } \\
\text { nogen }\end{array}$} & \multirow{2}{*}{$\begin{array}{c}\text { Total } \\
\text { protein }\end{array}$} & \multirow{2}{*}{ Albumin } & \multirow{2}{*}{ Globulin } & \multirow{2}{*}{$\begin{array}{l}\text { Albumin- } \\
\text { globulin } \\
\text { ratio }\end{array}$} & \multicolumn{2}{|c|}{ Serum bilirubin } \\
\hline & & & & & & & & & & & & & $1 \mathrm{~min}$. & total \\
\hline Group & $\begin{array}{l}\text { J. B. } \\
\text { C. W. } \\
\text { W. B. } \\
\text { G. C. } \\
\text { A. D. }\end{array}$ & $\begin{array}{l}35 \\
17 \\
11 \\
10 \\
13\end{array}$ & $\begin{array}{l}\mathbf{M} \\
\mathbf{M} \\
\mathbf{M} \\
\mathbf{M} \\
\mathbf{F}\end{array}$ & $\begin{array}{c}\text { per cent } \\
21 \\
2.7 \\
32 \\
-\end{array}$ & $\begin{array}{l}3 \\
1 \\
1 \\
4\end{array}$ & $\begin{array}{c}\text { units } \\
7 \\
6 \\
7 \\
4 \\
2\end{array}$ & $\begin{array}{c}\text { per cent } \\
75 \\
43 \\
60 \\
- \\
-\end{array}$ & $\begin{array}{c}\text { mg. } \\
\text { per day } \\
1.2 \\
17.0 \\
5.2 \\
3.8 \\
6.1\end{array}$ & \begin{tabular}{|c|} 
Gm. \\
per cent \\
5.8 \\
5.9 \\
6.95 \\
4.8 \\
6.4
\end{tabular} & $\begin{array}{c}\mathrm{Gm} . \\
\text { per cent } \\
2.75 \\
3.7 \\
3.1 \\
2.6 \\
3.1\end{array}$ & \begin{tabular}{|c|} 
Gm. \\
per cent \\
3.09 \\
2.2 \\
3.85 \\
2.2 \\
3.3
\end{tabular} & $\begin{array}{l}0.87 \\
1.68 \\
0.80 \\
1.18 \\
0.94\end{array}$ & $\begin{array}{c}\text { mg. } \\
\text { per cent } \\
0.02 \\
0.24 \\
0.4 \\
0.25 \\
0.07\end{array}$ & $\begin{array}{c}\text { mg. } \\
\text { per cent } \\
0.40 \\
2.52 \\
0.85 \\
0.45 \\
2.45\end{array}$ \\
\hline Group & $\begin{array}{l}\text { B. C. } \\
\text { B. R. } \\
\text { A. C. }\end{array}$ & $\begin{array}{l}60 \\
15 \\
19\end{array}$ & $\begin{array}{l}\mathbf{M} \\
\mathbf{M} \\
\mathbf{M}\end{array}$ & $\begin{array}{c}23 \\
7.9 \\
19\end{array}$ & $\begin{array}{l}3 \\
3 \\
0\end{array}$ & $\begin{array}{l}5 \\
3 \\
6\end{array}$ & $\begin{array}{l}19 \\
60 \\
43\end{array}$ & $\begin{array}{r}0.1 \\
6.0 \\
40.0\end{array}$ & $\begin{array}{l}6.0 \\
6.15 \\
7.25\end{array}$ & $\begin{array}{l}3.4 \\
2.84 \\
4.0\end{array}$ & $\begin{array}{l}3.6 \\
3.21 \\
3.25\end{array}$ & $\begin{array}{l}0.90 \\
0.88 \\
1.23\end{array}$ & $\begin{array}{l}0.32 \\
0.16 \\
-\end{array}$ & $\begin{array}{l}4.06 \\
0.23 \\
-\end{array}$ \\
\hline $\begin{array}{c}\text { Group } \\
\text { III }\end{array}$ & $\begin{array}{l}\text { O. B. } \\
\text { G. L. } \\
\text { S. L. } \\
\text { F. J. } \\
\text { C. T. } \\
\text { F. T. }\end{array}$ & $\begin{array}{l}29 \\
19 \\
57 \\
20 \\
31 \\
31\end{array}$ & $\begin{array}{l}\mathbf{F} \\
\mathbf{F} \\
\mathbf{F} \\
\mathbf{F} \\
\mathbf{M} \\
\mathbf{M}\end{array}$ & $\begin{array}{l}48 \\
18 \\
28 \\
31 \\
52.8 \\
19.0\end{array}$ & $\begin{array}{l}0 \\
1 \\
3 \\
3 \\
4 \\
4\end{array}$ & $\begin{array}{r}16 \\
2 \\
4 \\
2 \\
1 \\
\end{array}$ & $\begin{array}{l}\frac{43}{75} \\
33 \\
-\end{array}$ & $\begin{array}{c}0.18 \\
32 \\
65 \\
-\overline{250} \\
274\end{array}$ & $\begin{array}{l}5.8 \\
5.9 \\
6.7 \\
4.8 \\
5.5 \\
4.3\end{array}$ & $\begin{array}{l}2.3 \\
3.3 \\
2.8 \\
2.05 \\
3.1 \\
2.4\end{array}$ & $\begin{array}{l}3.5 \\
2.6 \\
3.9 \\
2.75 \\
2.4 \\
1.9\end{array}$ & $\begin{array}{l}0.66 \\
1.27 \\
0.71 \\
0.74 \\
1.29 \\
1.26\end{array}$ & $\begin{array}{l}1.7 \\
4.6 \\
1.34 \\
\overline{9.02} \\
0.7\end{array}$ & $\begin{array}{c}5.39 \\
7.55 \\
2.17 \\
13.85 \\
1.2\end{array}$ \\
\hline
\end{tabular}


TABLE II

J. B., N. M., 35, 4 per cent third degree burn

\begin{tabular}{|c|c|c|c|c|c|c|c|c|c|c|c|}
\hline \multirow{2}{*}{ Date } & \multirow{2}{*}{$\begin{array}{l}\text { Days } \\
\text { post- } \\
\text { burn }\end{array}$} & \multirow{2}{*}{$\begin{array}{l}\text { B.S.P. } \\
\text { retention }\end{array}$} & \multirow{2}{*}{$\begin{array}{l}\text { Cephalin } \\
\text { flocculation }\end{array}$} & \multirow{2}{*}{$\begin{array}{l}\text { Thymol } \\
\text { turbidity }\end{array}$} & \multirow{2}{*}{$\begin{array}{l}\text { Prothrombin } \\
\text { concentra- } \\
\text { tion }\end{array}$} & \multirow{2}{*}{$\begin{array}{c}\text { Total } \\
\text { protein }\end{array}$} & \multirow{2}{*}{ Albumin } & \multirow{2}{*}{ Globulin } & \multicolumn{2}{|c|}{ Serum bilirubin } & \multirow{2}{*}{ A/G ratio } \\
\hline & & & & & & & & & $1 \mathrm{~min}$. & total & \\
\hline \multirow{18}{*}{$\begin{array}{l}10-26 \\
10-27 \\
10-28 \\
11-1 \\
11-3 \\
11-4 \\
11-7 \\
11-10 \\
11-12 \\
11-17 \\
11-19 \\
11-23 \\
11-28 \\
11-30 \\
12-1 \\
12-8 \\
12-10 \\
12-15 \\
12-16 \\
12-17 \\
12-22\end{array}$} & & per cent & \multirow{18}{*}{$3^{+}$} & units & per cent & Gm. per cent & Gm. per cent & Gm. per cent & mg. per cen & mg. per cent & \\
\hline & & 12 & & 1 & 100 & 6.58 & 3.87 & 2.71 & 0.12 & 1.09 & 1.43 \\
\hline & 2 & & & & & 5.37 & 3.10 & 2.17 & 0.07 & 0.71 & 1.43 \\
\hline & 3 & & & & 75 & 5.58 & 2.75 & 2.83 & & & 0.97 \\
\hline & 7 & 14.4 & & 5 & 100 & 5.8 & 2.71 & 3.09 & 0.11 & 0.40 & 0.87 \\
\hline & $\begin{array}{r}9 \\
10\end{array}$ & 21.3 & & 7 & 75 & 6.14 & 335 & 270 & 0.11 & 0.18 & 120 \\
\hline & 13 & & & & & 0.14 & 0.05 & 2.19 & 0.02 & 0.30 & 1.20 \\
\hline & 16 & & & & & & & & 0.01 & 0.46 & \\
\hline & 18 & 19 & & 1 & 75 & 6.10 & 2.58 & 3.52 & & & 0.73 \\
\hline & $\begin{array}{l}23 \\
25\end{array}$ & & & 2 & 50 & 6.50 & 3.6 & 2.1 & $\begin{array}{l}0.02 \\
0.07\end{array}$ & $\begin{array}{l}0.12 \\
0.46\end{array}$ & 1.16 \\
\hline & 29 & 5.4 & & & & & & & 0.05 & 1.03 & \\
\hline & $\begin{array}{l}35 \\
37\end{array}$ & & & 2.5 & 00 & 0.24 & 3.1 & 3.14 & 0.1 & 0.55 & 0.98 \\
\hline & 38 & 22.8 & & & & & & & 0.14 & 0.56 & \\
\hline & 40 & & & 2 & 75 & 5.6 & 2.84 & 2.76 & & & 1.03 \\
\hline & $\begin{array}{l}45 \\
47\end{array}$ & 25.0 & & 2 & 60 & 5.6 & 26 & 30 & 0.15 & 0.71 & 086 \\
\hline & 52 & & & & & & & & 0.10 & 0.28 & \\
\hline & $\begin{array}{l}53 \\
54\end{array}$ & 10.9 & & & & & & & & & \\
\hline & 59 & 4.6 & & 3 & 60 & 5.8 & 2.84 & 2.96 & 0.11 & 0.56 & 1.15 \\
\hline
\end{tabular}

tion tests were done showed elevated values. Total serum proteins were slightly lowered in all except one of these patients, and the albumin-globulin ratios were decreased.

In one patient who was followed for a period of about 60 days, and whose protocol is shown in Table II we see a constant bromsulfalein retention until the time of complete healing. Cephalin flocculation, and thymol turbidity were increased at first, but the thymol turbidity was not abnormal after the tenth post-burn day. In this instance repeated determination of the serum bilirubin was normal, and the urine urobilinogen excretion did not become abnormal at any time, but the urinary coproporphyrin ${ }^{6}$ was definitely elevated until just before complete healing was accomplished and the patient discharged. The total protein data showed an initial low normal total protein with a normal ratio of albumin and globulin, but by the seventh day the albumin fraction had decreased so that the globulin was now greater, and there remained a disturbance of this ratio for the next 40 days, despite an adequate protein intake of over $100 \mathrm{Gm}$. per day with a caloric intake of 45 Calories per kilogram. Identical changes in the total protein and albumin-globulin ratios were observed in the three

\footnotetext{
6 These data have been presented elsewhere (1).
}

other patients in this group. The only patient who did not show the reversal of the $A / G$ ratio and no decrease in the total protein was a boy with a 35 per cent first and second degree burn. He also did not show any change in the B.S.P. retention.

In three patients (Table I) who had greater than 10 per cent third degree burn, but less than 20 per cent burn, all showed B.S.P. retention, but in one of them it was only 7.9 per cent. The cephalin flocculation was abnormal in two patients but the changes in the thymol turbidity were not marked. Two patients received aureomycin and in one the urine urobilinogen excretion was modified by this drug. The other, B. R., had an increased excretion of urinary urobilinogen probably because severe nausea and vomiting prevented retention of the oral aureomycin. Table I gives the other data collected for these three patients.

In one patient, B. C., who was followed for as long as 135 days there was an abnormal B.S.P. retention for over a month. Table III gives the complete data. He had an increased "indirect" serum bilirubin the second day after the burn. In spite of an adequate diet with a protein intake of over $100 \mathrm{Gm}$. daily there was a marked alteration of the albumin-globulin ratio and a lowered total se- 
TABLE III

B. C., W. M., 60, 11.5 per cent third degree burn

\begin{tabular}{|c|c|c|c|c|c|c|c|c|c|c|c|}
\hline \multirow{2}{*}{ Date } & \multirow{2}{*}{$\begin{array}{l}\text { Days } \\
\text { post- } \\
\text { burn }\end{array}$} & \multirow{2}{*}{$\begin{array}{l}\text { B.S.P. } \\
\text { retention }\end{array}$} & \multirow{2}{*}{$\begin{array}{c}\text { Cephalin } \\
\text { flocculation }\end{array}$} & \multirow{2}{*}{$\begin{array}{l}\text { Thymol } \\
\text { turbidity }\end{array}$} & \multirow{2}{*}{$\begin{array}{c}\text { Prothrombin } \\
\text { concentra- } \\
\text { tion }\end{array}$} & \multirow{2}{*}{$\begin{array}{c}\text { Total } \\
\text { protein }\end{array}$} & \multirow{2}{*}{ Albumin } & \multirow{2}{*}{ Globulin } & \multirow{2}{*}{ A/G ratio } & \multicolumn{2}{|c|}{ Serum bilirutin } \\
\hline & & & & & & & & & & $1 \mathrm{~min}$. & total \\
\hline & & per cent & & units & per cent & $\underset{\text { per cent }}{G m .}$ & $\underset{\text { per cent }}{G m .}$ & $\underset{\text { per cent }}{G m .}$ & & $\begin{array}{c}m g . \\
\text { per cent }\end{array}$ & $\begin{array}{l}m g . \\
\text { per cent }\end{array}$ \\
\hline $12-9-49$ & 0 & & & 5 & 75 & 6.1 & 4.4 & 1.7 & 2.58 & 0.3 & 1.95 \\
\hline $12-10$ & 1 & 22.3 & 0 & & 60 & 6.0 & 3.4 & 3.6 & 0.9 & 0.32 & 4.06 \\
\hline $12-12$ & 3 & & $3^{+}$ & 2 & & & & & & 0.91 & 2.89 \\
\hline $\begin{array}{l}12-15 \\
12-16\end{array}$ & 6 & 23.1 & & & & 4.8 & & 1.7 & 1.82 & & \\
\hline $\begin{array}{l}12-10 \\
12-17\end{array}$ & 8 & & 0 & 3 & 27 & 5.2 & 2.84 & 2.36 & 1.2 & 0.12 & 0.65 \\
\hline $12-20$ & 11 & & & & 100 & & & & & & \\
\hline $12-22$ & 13 & 13.2 & 0 & 3 & 60 & 4.6 & 2.3 & 2.3 & 1.0 & 0.08 & 0.80 \\
\hline $12-27$ & 18 & & 0 & 2 & 50 & 5.0 & 1.6 & 3.4 & 0.47 & & \\
\hline $\begin{array}{l}12-30 \\
1-4-50\end{array}$ & $\begin{array}{l}21 \\
26\end{array}$ & 12.2 & & & 100 & 5.6 & 1.7 & 3.95 & 0.43 & & \\
\hline $\begin{array}{l}1-7 \\
1-9\end{array}$ & 29 & 2.79 & & 47 & & & & & & 0.05 & 0.22 \\
\hline $\begin{array}{l}1-9 \\
1-10\end{array}$ & $\begin{array}{l}31 \\
32\end{array}$ & & 0 & 4.1 & & & & & & & \\
\hline $1-30$ & 52 & & 0 & 9.0 & 60 & 6.63 & 2.85 & 3.78 & 0.75 & & \\
\hline $2-9$ & 62 & & 0 & 9.5 & 100 & 5.4 & 2.6 & 2.8 & 0.93 & & \\
\hline $2-21$ & 74 & & & & & 6.45 & 3.2 & 3.2 & 1.0 & & \\
\hline $3-15$ & 96 & & 0 & 7.0 & & 6.39 & 2. & 3.89 & 0.64 & & \\
\hline $3-28$ & 109 & & & & & 5.73 & 3.0 & 2.73 & 1.10 & & \\
\hline $4-7$ & 119 & & $2^{+}$ & 8.0 & 100 & 6.18 & 3.3 & 2.8 & 1.18 & & \\
\hline $\begin{array}{l}4-19 \\
4-24\end{array}$ & $\begin{array}{l}130 \\
135\end{array}$ & & & & & $\begin{array}{l}6.97 \\
5.36\end{array}$ & 3.58 & 1.78 & 2.05 & & \\
\hline & & & & & & & & & & & \\
\hline
\end{tabular}

rum protein. Even at 96 days following the burn total serum proteins were still abnormal. The same changes were observed in two other patients, both of whom had adequate dietary intake.

In six patients who had burns of greater than 20 per cent third degree the changes in the liver function were seemingly much more marked. All patients had a marked retention of the B.S.P. dye. In all except two the cephalin flocculation was three plus or greater and there was a marked increase in the urine urobilinogen in all except one (O. B.) who developed severe oliguria and uremia. Four patients developed jaundice and five showed significant increases in the one minute fraction of the bilirubin determination. One man in this group was followed for a period of 32 days before his death and he developed outstanding changes in the total protein and albumin-globulin ratio. The albumin fraction remained for long periods around $1 \mathrm{Gm}$. and the total protein slightly over $5 \mathrm{Gm}$. per cent. These data are presented in Table IV. Electrophoretic studies of the serum proteins were performed on many of the patients reported in this paper. Changes were evident in all the protein fractions. This work is to be reported elsewhere (19).
In all third degree burns from the small to the most extensive there appears to be involvement of the functional state of the liver as judged by the usual liver function tests. It is suggested by our data that the more extensive the burn the greater the functional damage.

All of our patients who had more than the 20 per cent third degree burn succumbed and autopsies were performed on five of the six. The autopsy material demonstrated pathologic changes in the

TABLE IV

F. T., W. M., 32, 30 per cent third degree burn

\begin{tabular}{c|c|c|c|c|c}
\hline \hline Date & $\begin{array}{c}\text { Days } \\
\text { post burn }\end{array}$ & $\begin{array}{c}\text { Total } \\
\text { protein }\end{array}$ & Albumin & Globulin & A/G ratio \\
\cline { 1 - 3 } \cline { 1 - 1 } & 0 & $\begin{array}{c}\text { Gm. } \\
\text { per cent }\end{array}$ & $\begin{array}{c}\text { Gm. } \\
\text { per cent }\end{array}$ & $\begin{array}{c}\text { Gm. } \\
\text { per cent }\end{array}$ & \\
$9-23$ & 1 & 4.8 & 3.2 & 1.6 & 2.0 \\
$9-24$ & 2 & 4.7 & 2.9 & 1.8 & 1.61 \\
$9-24$ & 3 & 3.6 & & & \\
$9-25$ & 4 & 5.0 & & & \\
$9-26$ & 5 & 4.3 & 2.4 & 1.9 & 1.26 \\
$9-27$ & 12 & 5.1 & 1.3 & 3.8 & 0.33 \\
$1-4$ & 15 & 5.1 & 1.1 & 4.0 & 0.37 \\
$1-7$ & 19 & 5.2 & 1.0 & 4.5 & 0.22 \\
$1-11$ & 21 & 5.5 & 1.7 & 3.8 & 0.44 \\
$1-14$ & 22 & 4.9 & 1.7 & 3.8 & 0.44 \\
$1-15$ & 25 & 6.2 & 2.9 & 3.3 & 0.88 \\
$1-18$ & 35 & 4.8 & 2.4 & 2.4 & 1.00 \\
$1-28$ & 35 & & &
\end{tabular}


livers of all the patients who died. There did not appear to be any definite pattern of pathologic alteration. In one man, F. T., with 30 per cent third degree and 95 per cent total burn who lived for 32 days the histology of the liver showed central vein changes, with sinusoidal congestion and generalized cloudy swelling and fat deposition more marked in the peripheral zones of the liver lobule. Many of the von Kupfer cells contained yellowish pigment, slightly granular in quality, which might be iron. These changes may be seen in Figures 1 and 1a. In another, O. B., a 29 year old negro female with 65 per cent third degree, there was a marked central congestion, degeneration, and necrosis, with an accumulation of polymorphonuclear neutrophiles in this area. As in F. T., yellowish brown pigment was prominent in the von Kupfer cells. In the areas of necrosis were observed macrophages with eosinophilic cytoplasm, and in the midzonal regions in addition to polymorphonuclear infiltration there were accumulations of lymphocytes with macrophages which appeared to be erythrophagocytic. Figures 2 and 2a show these changes. In another patient, G. L., a 51 per cent third degree, there were changes showing sinusoidal congestion, cloudy swelling, and minimal fatty degeneration in the central vein area. There appeared to be some increase in lymphocytes in the portal area. No focal necrosis was seen. The von Kupfer cells in some places appeared prominent. Figures 3 and 3 a show the pathological changes.

That these changes occur early is indicated by the last two cases described. Both patients had severe burns and lived five and four days respectively. The necropsies were done within five hours post-mortem. The possibility that the changes observed were due to post-mortem autolysis is unlikely.

The weights and gross appearance of the liver is recorded in Table V. Generally there was not much to be observed from the gross specimens, other than slight enlargement. Gross fatty changes were not prominent.

It would appear from these observations that in addition to changes in liver function tests, there are histopathological changes in the liver. No correlation exists, and we have no biopsy data on the less severe burns. The mechanism by which
TABLE $V$

\begin{tabular}{|c|c|c|c|c|}
\hline Patient & $\begin{array}{l}\text { Amount } \\
\text { of third } \\
\text { degree }\end{array}$ & $\begin{array}{l}\text { Hours } \\
\text { post- } \\
\text { mortem }\end{array}$ & Weight & Description \\
\hline $\begin{array}{l}\text { F. T. } \\
\text { W. M. } 30\end{array}$ & $\begin{array}{c}\text { per cent } \\
30\end{array}$ & 12 & 2,350 & $\begin{array}{l}\text { External surface smooth: } \\
\text { edges rounded, reddish- } \\
\text { brown in color. Cut sur- } \\
\text { face bleeds easily. }\end{array}$ \\
\hline N. M. M. 84 & 38 & 29 & 1.800 & $\begin{array}{l}\text { Firm, smooth, light brown } \\
\text { in color. Few pale areas } \\
\text { in parenchyma. }\end{array}$ \\
\hline N.F. L., 19 & 51 & 5 & 1.870 & $\begin{array}{l}\text { Bluish red, with firm con- } \\
\text { sistency; internal architec- } \\
\text { ture and vascular mark- } \\
\text { ings prominent. }\end{array}$ \\
\hline N. F. J., 20 & 55 & 15 & 1,425 & $\begin{array}{l}\text { Surface pale yellowish and } \\
\text { smooth; cut parenchymal } \\
\text { surface bulges; lobular } \\
\text { pattern distinct and gen- } \\
\text { erally yellowish color. }\end{array}$ \\
\hline $\begin{array}{l}\text { O. B. } \\
\text { N. F., } 29\end{array}$ & 65 & 2 & 1,840 & $\begin{array}{l}\text { Cut surface is fatty, bulges; } \\
\text { congestion in the center of } \\
\text { the lobule. }\end{array}$ \\
\hline
\end{tabular}

these changes were produced is not evident, but speculation leads us to wonder about the absorption of products of tissue disintegration from the burned surface. Shock was prevented and we have no reason to believe that there was a diminution of blood flow to the liver to produce these changes. Hourly urine output was good and was used as an index of renal blood flow. Certainly the greater the amount of third degree burn the more marked were the changes in liver function. We would tend to agree with the statements of Gillman and Gillman (5), that if the liver plays a part in causing the death of the burned individual it does so at a level where fundamental biochemical processes involving protein synthesis, detoxification, and probably reticulo-endothelial activity are impaired. The finding of erythrophagocytosis in one patient suggests that mechanism may play a part in the anemia of thermal burns.

The early appearance of changes in liver function suggests the advisability of initiating immediate preventive therapy against liver damage whether it be due to the absorption of products of tissue damage or due to profound alterations in hepatic physiology produced by a sudden stress phenomenon. Preliminary trials by us, using dietary measure and in one patient lipotropic agents such as methionine, have been generally ineffective. By diminishing the reabsorption of urobilinogen, we thought we might remove a functional load on the liver, and so aureomycin was administered orally. We observed no beneficial effect of aureomycin in these individuals in so far as changes in the liver function are concerned. 


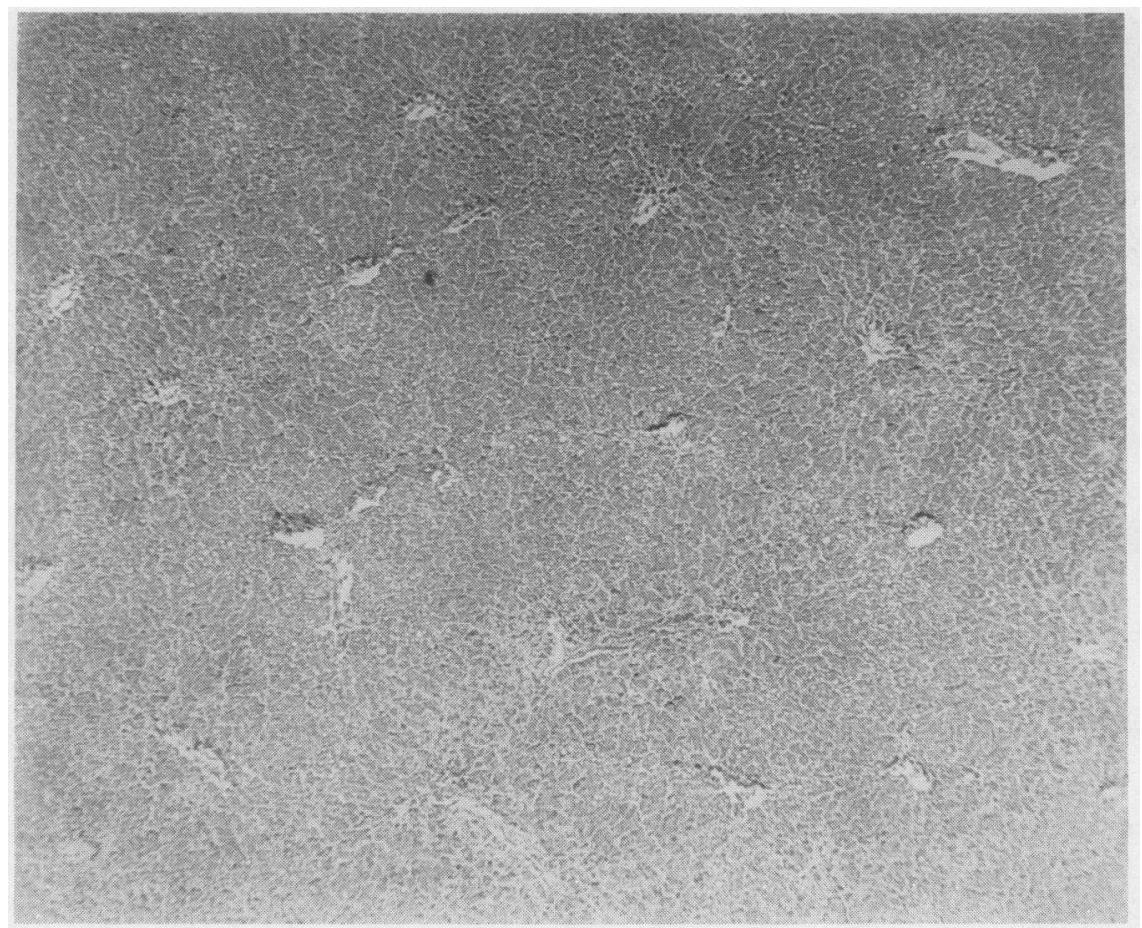

FIG. 1

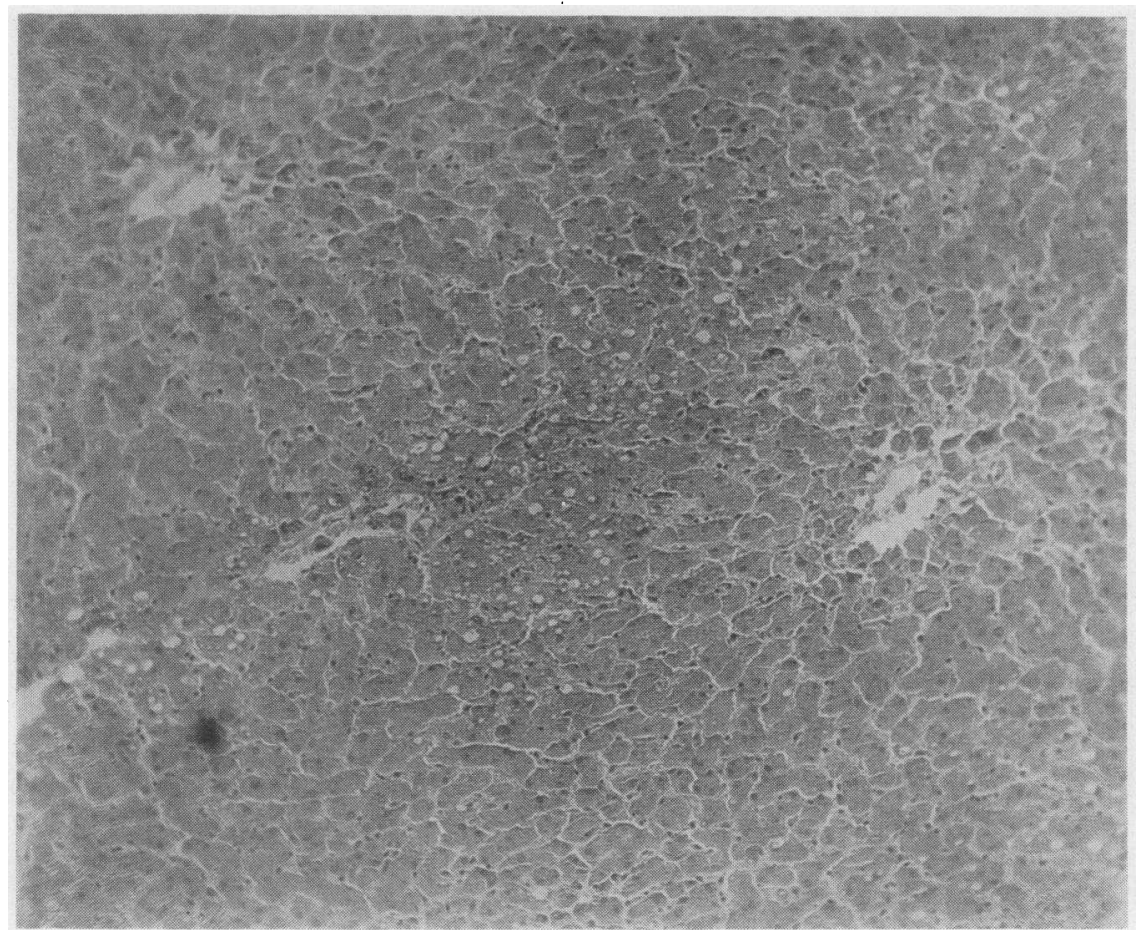

FIG. 1a

Figures 1 and 1a are taken of liver sections from patient $\mathrm{F}$. T. who had 30 per cent third degree and 95 per cent total burn. Note the generalized cloudy swelling, sinusoidal congestion, and the fatty infiltration and fat lobules in the portal areas. There was marked urine urobilinogen excretion just prior to death. 


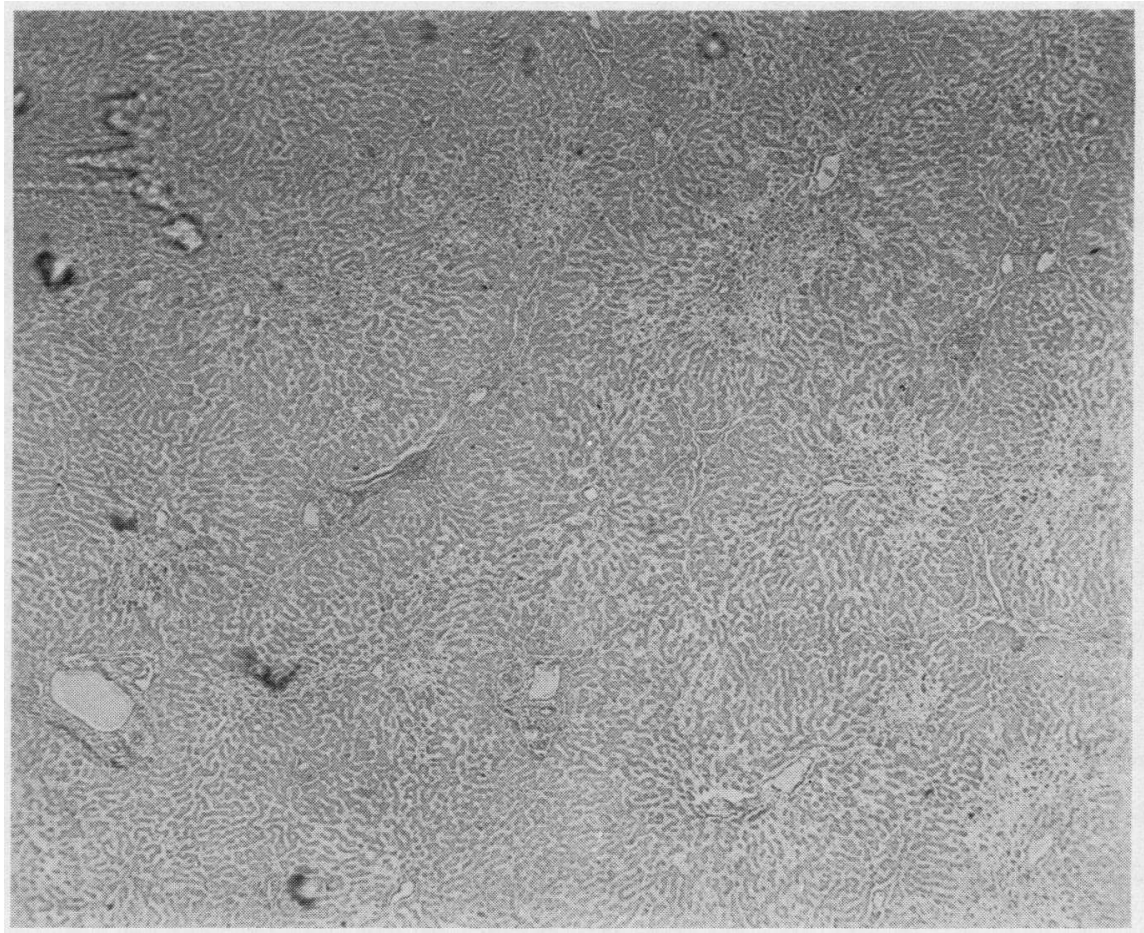

FIG. 2



Frg. 2a

Figures 2 and $2 \mathrm{a}$ are taken of the liver sections from the patient $O$. B. with 65 per cent third degree burns. Note the marked sinusoidal congestion, areas of focal necrosis, and cloudy swelling. Eosinophilic macrophages were present and erythrophagocytosis observed. In some areas hyalinized eosinophilic bodies were seen. 




FIG. 3

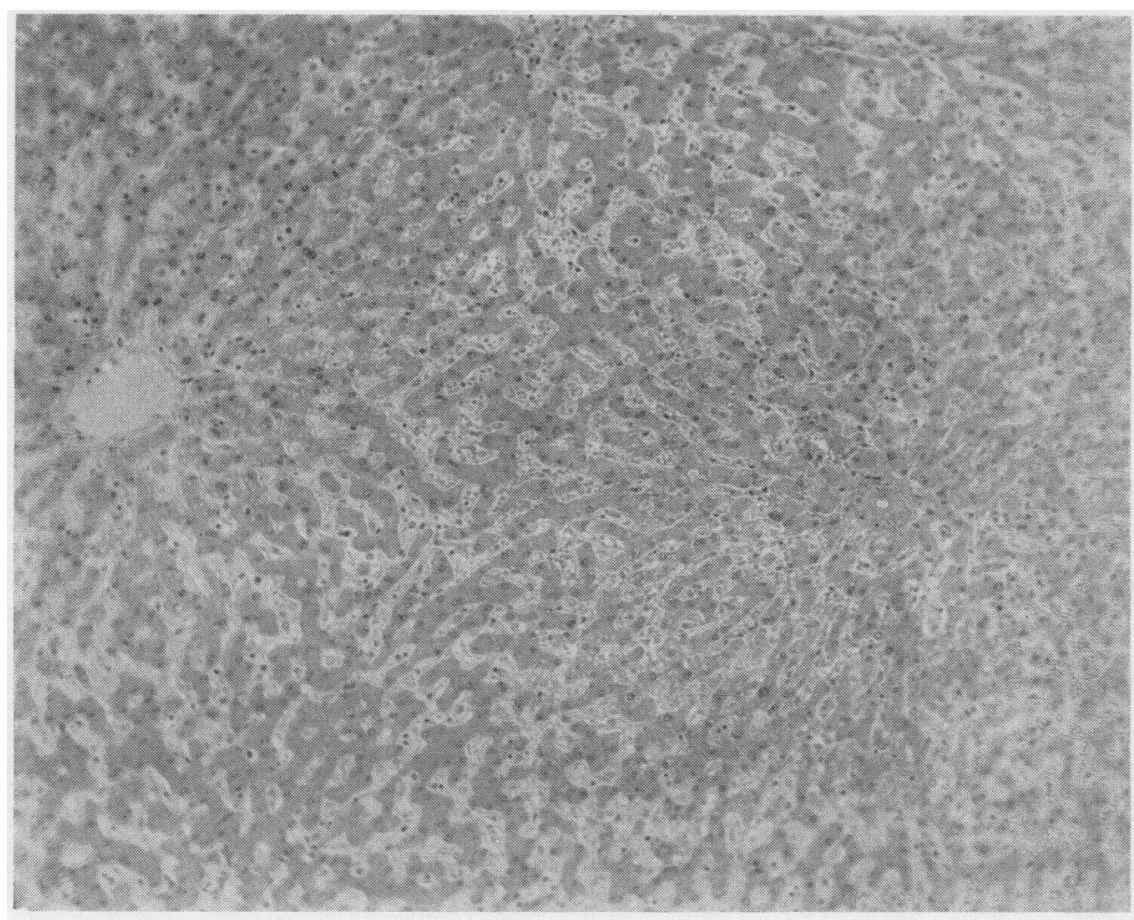

FIG. 3a

Figures 3 and $3 \mathrm{a}$ are from the liver sections of G. L. who suffered a 51 per cent third degree burn. There is sinusoidal congestion, cloudy swelling, and minimal fatty degeneration in the central vein areas. No focal necrosis was observed. 
Two of the patients were on diets which provided very high protein and carbohydrate intakes with practically no fat. Milk protein and milk products formed the base of the diets and vitamin supplements were given in the quantities recommended by the National Research Council. The patients on this regime still manifested marked changes in the albumin-globulin ratio and in the B.S.P. retention as well as in the other liver function tests employed. We might speculate that this apparent disturbance in protein synthesis and/or excessive albumin loss probably has some part in the anemia of thermal injury through impaired globin synthesis.

\section{CONCLUSIONS}

Minor to extensive third degree burns show early impairment of the liver function as judged by changes in the liver function tests employed in this study. The more severe the burn the greater the amount of change in liver function.

One of the most constant changes was the increase in urine urobilinogen excretion and alterations in the albumin-globulin ratio, both considered to be sensitive evidences of liver function.

Autopsy material on five fatal burns showed no constant histopathological change, but there was evidence of fatty infiltration, cloudy swelling, increased pigments in the reticulo-endothelial cells, focal necrosis, and congestion in the liver substance.

More study is necessary to understand the mechanism whereby liver function failure occurs and attention should be directed at the prevention. as well as treatment, of liver dysfunction in severe burns.

\section{REFERENCES}

1. James, G. Watson, III, Purnell, O. J., and Evans, E. I., The anemia of thermal injury. I. Studies of pigment excretion. J. Clin. Invest., 1951, 30, 181.

2. Bardeen, C. R., A review of the pathology of superficial burns, with a contribution to our knowledge of the pathological changes in the organs in cases of rapidly fatal burns. Johns Hopkins Hospital Reports, 1898, 7, 137.
3. Wolff, W. A., Elkinton, J. R., and Rhoads, J. E., Liver damage and dextrose tolerance in severe burns. Ann. Surg., 1940, 112, 158.

4. Boyce, F. F., The hepatic (hepatorenal) factor in burns. Arch. Surg., 1943, 44, 799.

5. Gillman, J., and Gillman, T., Structure of the liver in fatal burns. South African J. M. Sc., 1948, 13, 169.

6. Wells, D. B., Humphrey, H. D., and Coll, J. J., Relation of tannic acid to liver necrosis occurring in burns. New England J. Med., 1942, 226, 629.

7. Forbes, J. C., and Evans, E. I., Tannic acid and liver necrosis. Surg., Gynec. \& Obstet., 1943, 76, 612.

8. Duffin, J. D., Liver necrosis following burns. Can. M. A. J., 1942, 47, 138.

9. Baker, R. D., The internal lesions in burns with special reference to the liver and to splenic nodules. An analysis of 96 autopsies. Am. J. Path., 1944, 21, 717.

10. Hartmann, F. W., and Romence, H. L., Liver necrosis in burns. Ann. Surg., 1943, 118, 402.

11. Belt, T. H., Liver necrosis following burns, simulating the lesions of yellow fever. J. Path. \& Bact., 1939, 48, 493.

12. Gaebler, O. H., Determination of bromsulphalein in normal, turbid, hemolyzed, or icteric serums. Am. J. Clin. Path., 1945, 15, 452.

13. Hanger, F. M., Serological differentiation of obstruction from hepatogenous jaundice by flocculation of cephalin-cholesterol emulsions. J. Clin. Invest., 1939, 18, 261.

14. Shank, R. E., and Hoagland, C. L., A modified method for the quantitative determination of the thymol turbidity reaction of serum. J. Biol. Chem., 1946, $162,133$.

15. Quick, A. J., Stanley-Brown, M., and Bancroft, F. W., A study of the coagulation defect in hemophilia and in jaundice. Am. J. M. Sc., 1935, 190, 501.

16. Kingsley, G. R., Direct biuret method for the determination of serum proteins as applied to photoelectric and visual colorimetry. J. Lab. \& Clin. Med., 1941-42, 27, 840.

17. Ducci, H., and Watson, C. J., The quantitative determination of the serum bilirubin with special reference to the prompt-reacting and chloroformsoluble types. J. Lab. \& Clin. Med., 1945, 30, 293.

18. Schwartz, S., Sborov, V., and Watson, C. J., Studies of urobilinogen. IV. The quantitative determination of urobilinogen by means of the Evelyn photoelectric colorimeter. Am. J. Clin. Path., 1944, 14, 598.

19. Robinett, P. W., Personal communication. 